\title{
Importance of Social Responsibility: An Employee Standpoint
}

\author{
Naval Lawande
}

\begin{abstract}
The present study revolves around the key theme of importance of social responsibility and to recognize the employees' viewpoint on the social initiatives taken up by the firm. How do the employees relate to Corporate Social Responsibility (hereafter CSR) in terms of its importance and benefits to self as well as the organization? In this paper the researcher attempts to explore the perspective of managers/executives/administrators across various sectors. Their sentiments towards CSR, especially its benefits and its importance are analyzed. A questionnaire developed by the researcher was administered to capture the responses of the participants. The data sample consisted of 336 managers/executives/administrators from firms based in and around Pune region. The findings depict that effective implementation of CSR initiatives may lead to lowering of attrition levels in the firm. Also, employees believe that fair remuneration would be an ideal indicator of whether an organization is socially responsible or not. Results of the exploratory research draw attention to the inevitability of CSR aiding ethical behaviors amongst employees. Nurturing the importance towards CSR in employees and ensuring relevant benefits to the firm is the need of the hour. This research article has vital inferences for firms and their managers, especially as it relates to the viewpoints of the internal stakeholders towards CSR. Some explanations as well as limited generalizations and implications are developed thereof.
\end{abstract}

Keywords: Employee viewpoint, Social Responsibility, CSR.

\section{INTRODUCTION}

In most developing countries like India, other than public sector companies, private sector is one of the largest contributors to Corporate Social Responsibility (hereafter CSR) spending. The earlier notion was that CSR is only philanthropy. Nonetheless, today CSR is a far more multifaceted concept and takes cognizance of not only external stakeholders. CSR has climbed the ladder of the priority list for most companies, especially private sector. The Indian corporate perceives CSR as a cyclical act that benefits the firm as it benefits the world. For instance, educating the rural customer on benefits of banking is in the long run beneficial for the firm itself.

The human elements in organizations have gained enormous importance since the $20^{\text {th }}$ century. Human elements are very difficult to manage and it requires a great deal of expertise on the manager's part. Research has shown significant correlation between the human elements and firm performance. The Indian Industry has been taking the human element very seriously of late. This element consists of the knowledge, skill, talent of a firm's workforce, as well

Revised Manuscript Received on September 10, 2019.

Dr. Naval Lawande, Assistant Professor, Symbiosis Institute of Management Studies, Pune, Maharashtra, India.

(Email: naval.lawande@gmail.com) as the values, attitudes and beliefs of the individuals involved in it.

In today's fast changing world, one of the most critical factors for business success is the intellectual capital the firm holds; most managers would surely agree to this statement. Knowledge is more important than ever before and a major source of competitive advantage. Not only are employees the most decisive resource, they also determine the success of every activity within the organization Employees are termed as strategic assets of the $21^{\text {st }}$ century.

Just as organizations have changes dramatically in nature over the last 20 years, so have employees' attitudes towards their employers - and attitudes towards social initiatives is no exception. Employees are increasingly aware of their own values as well as that if the employer. Most of the $21^{\text {st }}$ century Multinational companies (hereafter MNC) have become larger and more influential than governments of countries they operate in. However, these MNC's have realized that with this shift of resources necessarily comes a shift in responsibility to positively and proactively impact the community around them. CSR is no more just an expectation; it has evolved to be the right thing to do. Managers and executives have understood that CSR can positively add value to the bottom line and foster sustainability of the business. In view of this, the research tries to answer the following questions:

- What does the concept of CSR mean to the employees?

- Does the employee give importance to the social initiatives of the firm?

- $\quad$ Do employees believe the CSR initiatives will reap any benefits to the firm?

\section{REVIEW OF LITERATURE}

A firm's active participation in CSR has a major impact on its employees. Firms that give importance to a CSR initiative do get branded as great employers. The relationship between business and society has been a matter of discussion in entire business diaspora. Businesses are experiencing tremendous pressure from all stakeholders on issues of sustainability, environment and ethicality. The internal stakeholder (viz. employee) is becoming more conscious and expects judicious use of business power held by the corporation and its executives.

A. Corporate Social Responsibility

Exuding socially responsible behavior has become a modern-day feature of the $21^{\text {st }}$ century businesses. 
Originating in the management arena, CSR has been embraced by other business-based disciplines such as organizational behavior and culture.

Elkington (1997) refers to the three main types of responsibilities an organization has to fulfill. Although number of researchers and scholars have conceptualized CSR numerous ways, in principle the economic, social and environmental aspects are the key aspects of CSR.

As Robbins (2005) puts it, the basic premise of CSR is the actions and accountability of the firm. This accountability is more than just the legal responsibility towards the shareholders, employees and other direct / indirect stakeholders. The firm should be expected to appreciate and acknowledge its full responsibility for the non-economic repercussions of its actions and activities. This is taking cognizance of the fact that its actions have wider implications on the local community, society and natural environment.

However, there has been an argument expressed by Daily et al (2003), that CSR has grown to enable companies alleviate their feelings of guilt. A guilt that emerges from the 'only profit' motive of firms. Most often than not this 'only profit' motive is at the expense of environmental sustainability and exploitation of labor in the process. The power MNC's currently exert has probably had an influence, not to ignore the challenges that accompany this power.

\section{B. Importance of Corporate Social Responsibility}

One of the key reasons for increase in the importance of CSR is the fact that prospective employees (viz. job seekers) prefer to join organizations that have proclaimed themselves as being socially responsible. In a study conducted by Peterson (2004), it was established that corporate citizenship showcased by a firm has an effect on the commitment levels of its employees. The results also indicated that the relationship was stronger among employees who believed highly in the importance of the social responsibility of businesses.

As per the research conducted by Backhaus et al (2002) there exists a correlation between the CSR initiatives of a firm and its appeal in the job market. Job seekers tend to put employee relations, relations with society, protection of environment and quality of consumer products as their top priorities. These are some of the criteria in selection of the place of employment.

CSR has always been viewed as only being related to either environmental concerns or charity. However, in reality CSR is concerned with the plethora of interests and demands from all stakeholders of the firm. In fact, of late the internal stakeholders are gaining importance. The employee is well informed and has an opinion on the CSR initiatives of the firm.

The importance and attention given to CSR is very evident. Lately, companies across the length and breadth of India have begun appointment of CSR managers. HR departments have now an additional portfolio to manage. This portfolio includes design and implementation of CSR initiatives of the firm. The new CSR Rules under Companies Act 2013 makes it mandatory for companies to spend a minimum of $2 \%$ on CSR and also reporting the same. It takes into account the basic tenets of CSR: People, Planet and Profit. The mandatory social spending also demands robust monitoring mechanisms. Hence, measurement is a critical facet of the CSR projects and Programmes. The CSR Rules are only guiding principles and not the final outcome. Creativity and innovation in CSR initiatives is being welcomed by the top management.

The basic premise of CSR, at least in the Indian context is inclusive development and diminishing the disparity that exists in our country. The message is clear, community or society at large is not merely recipients of corporate philanthropy but are partners with a legitimate stake. Incorporating the social obligation into the firm's strategy and creating relevant value to all stakeholders is in best interest of the business itself.

A research on the Social Identity Theory literature states that if a firm engages in social initiatives, the employees tend to hold pride in being a member of such an organization. The employees believe it is a long-term view of the firm to care about the present and future of the world; even though it might not be a profitable decision in the first place. The employees would prefer to identify with an organization that is farsighted rather than myopic in nature.

Firms have begun to realize that CSR does not mean the same thing to all stakeholders, not even all of their employees. The communication strategies to spread the message for each stakeholder ought to be distinct and varied. The cultural aspects of the firm would play a pivotal role in such strategies.

External factors do have an influence on the way CSR is perceived in an organization. The importance an employee lays on the social initiatives of the firm is one such factor. If an employee has a belief that CSR is important and that a firm has social responsibilities over and above making profit; the employee may show higher levels of involvement in the CSR initiatives of the firm.

\section{RESEARCH OBJECTIVE}

The researcher proposes three objectives to the study. The first dimension of the research is to study the awareness of CSR amongst employees of various firms based in Pune. A scale developed by Duygu Turker (2008) is administered to capture this facet of the research. Secondly, to highlight the relationship between the ethical approach initiated by companies towards their employees and its influence on them. Thirdly, to inspect the effects of CSR initiatives of the firm on sustainability and related variables amongst its employees.

\section{METHODOLOGY}

CSR and its influence on various entities has been one of the most contemplating topics for many years now. The influence of CSR on various stakeholders has led to many thought provoking research. The research primarily attempts to deliberate on the question; is the employee today sensitive towards CSR initiatives taken up by the firm? The relationship between CSR and sustainability is receiving a lot of attention. Most studies indicate a linkage between 
CSR, sustainability and the degree of its importance. However, contextually there is no such research conducted in the Pune Region.

\section{A. Sampling Method:}

The respondents were selected from a population of managers/executives/administrators from firms based in and around Pune region. The respondents were employees of various ranks / levels / cadres. The participants comprised of 67 Senior Managers, 56 Managers, 114 executives and 99 administrators. The group consisted of 183 male and 153 female employees, within an age bracket of $29-45$ years.

\begin{tabular}{|l|l|l|}
\hline \multicolumn{3}{|l|}{ Table I: Demographics of Respondents } \\
\hline Gender & $\begin{array}{l}\text { No. } \\
\text { Respondents }\end{array}$ & $\begin{array}{l}\text { Percentag } \\
\text { e }\end{array}$ \\
\hline Male & 183 & $54 \%$ \\
\hline Female & 153 & $46 \%$ \\
\hline Designation / Position & $20 \%$ \\
\hline Sr. Manager & 67 & $17 \%$ \\
\hline Manager & 56 & $34 \%$ \\
\hline Executives & 114 & $29 \%$ \\
\hline $\begin{array}{l}\text { Administrato } \\
\text { rs }\end{array}$ & 99 & \\
\hline
\end{tabular}

\section{B. Research Instrument:}

The research instrument is a critical part of the primary data collection. Two different research instruments were used for the purpose of data collection. The first instrument is a scale designed by Duygu Turker (2006). This was primarily used to measure the general opinion of managers/executives/administrators from various firms. The scale consisted of 17 statements relating to social responsibility aspects concerning employees, environment and community. Responses to the statements was measured on a 5-point Likert scale. 'Totally Disagree' is represented by 1 and 'Totally Agree' represented by 5. Statements 6 to 10 categorically focused on the Importance of CSR. The instrument had a reliability value of 0.82 .

The second instrument was a questionnaire developed by the researcher was administered to capture the responses of the participants. The questionnaire consisted of two parts. The first part focused on the 'Importance' of CSR, as perceived by the respondent. The second part focused on the 'Benefits' of implementing CSR initiatives to the firm. The factors were identified based on the literature review.

\section{RESULTS}

The SPSS version 21.0 was used for purpose of analysis of data collected. Primarily Paired Samples t-test and Pearson correlation has been applied to derive at the necessary inferences. The main aspect being analyzed was the employee's importance towards CSR. Weighted average scores have been calculated to comprehend the level of agreement / disagreement. Also, the additional statement wise graphs help decipher the actual message in the responses.

A. Importance of Social responsibility and Employee directed CSR

Employees can be classified as internal stakeholders of a business. Their support is necessary for the effective implementation of CSR Programmes initiated by the firm.
CSR directed towards employees may be perceived positively by them. Could there be a linear relationship between the two variables? Hence the formulated hypothesis was:

H1:

there is a linear relationship between importance of CSR \& Employee directed CSR.

\begin{tabular}{|lr|l|l|l|l|}
\hline \multicolumn{6}{|l|}{ Table II: Basic Statistics } \\
\hline & $\begin{array}{l}\text { Mea } \\
n\end{array}$ & N & $\begin{array}{l}\text { Std. } \\
\text { Deviation }\end{array}$ & $\begin{array}{l}\text { Std. Error } \\
\text { Mean }\end{array}$ \\
\hline $\begin{array}{l}\text { Importance of } \\
\text { CSR }\end{array}$ & 4.12 & $\begin{array}{l}33 \\
6\end{array}$ & .908 & .050 \\
\hline $\begin{array}{l}\text { CSR to } \\
\text { Employees }\end{array}$ & 3.90 & $\begin{array}{l}33 \\
6\end{array}$ & .979 & .053 \\
\hline
\end{tabular}

\begin{tabular}{|l|l|l|l|l|l|}
\hline \multicolumn{7}{|l|}{ Table III. Paired Samples t - test } \\
\hline $\begin{array}{l}\text { Importance } \\
\text { of CSR - } \\
\text { CSR to } \\
\text { Employees }\end{array}$ & .226 & $\begin{array}{l}\text { Std. } \\
\text { Deviation }\end{array}$ & $t$ & $d f$ & $\begin{array}{l}\text { Sig. } \\
\text { (2-tailed) }\end{array}$ \\
\cline { 2 - 6 } & & .872 & 4.754 & 335 & .000 \\
\hline
\end{tabular}

\begin{tabular}{|l|l|l|l|}
\hline \multicolumn{4}{|l|}{ Table IV. Correlation between variables } \\
\hline $\begin{array}{l}\text { Importance of CSR \& CSR to } \\
\text { Employees }\end{array}$ & $N$ & $\begin{array}{l}\text { Correlati } \\
\text { on }\end{array}$ & Sig. \\
\cline { 2 - 5 } & $\mathbf{3 3 6}$ & .575 & .000 \\
\hline
\end{tabular}

Using 0.05 level of significance, $\mathrm{t}_{\text {STAT }}$ is 4.754 with 335 degrees of freedom. Also, the p - value is zero (which is less than 0.05). Table II and Table III hereby indicates that there is a linear relationship between 'Importance of CSR' and 'Employee directed CSR'. Table IV depicts the strength of the relationship as a positive 0.6 .

Inference:

There is a linear relationship between Employee directed CSR initiatives and Importance of CSR. Employees will tend to give greater importance to CSR Programmes when they are direct or indirect beneficiaries of the initiatives.

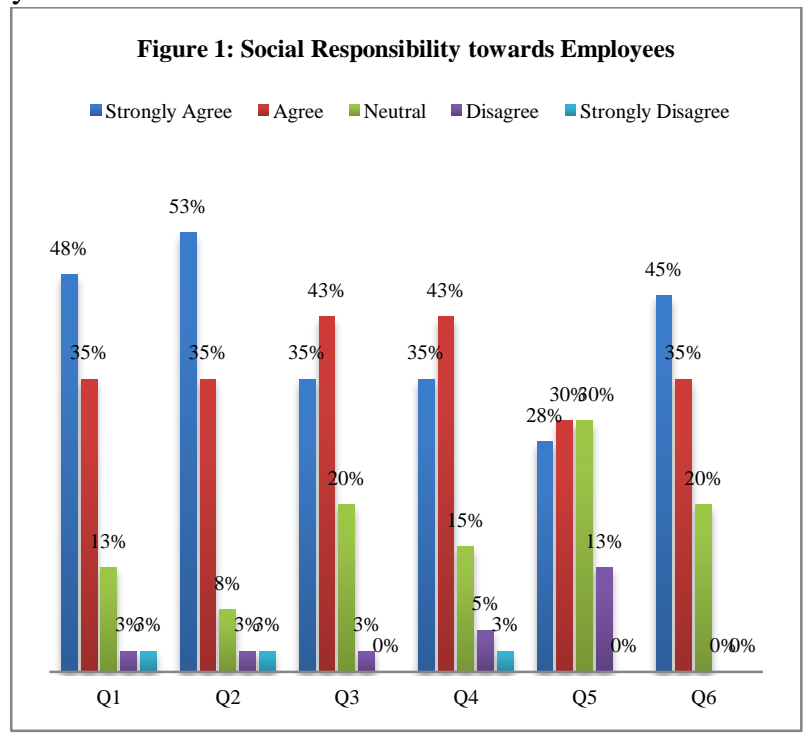

Published By 
Q1.

The company encourages participation in the voluntarily activities

Q2.

The company encourages its employees to develop their skills

Q3.

The management is primarily concerned about the employees' needs and wants

Q4.

The company implements flexible policies to provide a good work life balance for its employees

Q5.

The managerial decisions related with the employees are usually fair

Q6.

The company supports employees who want to acquire additional education.

Fig. 1 shows the responses of items $1-6$ of the questionnaire. The responses to Q2 \& Q6 in above figure illustrate that employees agree to the encouragement shown by firms in their personal development through education and career development Programmes. However, responses to Q3, Q4 \& Q5 are marginally differing. This could be because the employees consider work life balance, fairness in managerial decisions to be relevant to socially responsible behavior of the firm than developing their skills and careers.

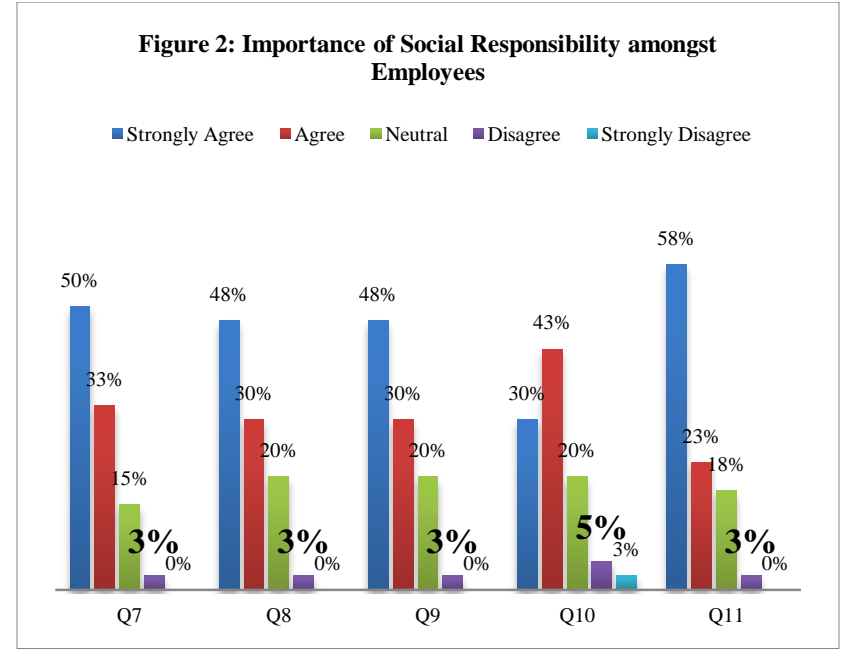

Q7.

Is being socially responsible is the most important thing a firm can do

$Q 8$.

The Social responsibility initiatives of a firm is essential to its long-term profitability

Q9.

Overall effectiveness of a business can be determined to by the degree to which it is socially responsible

Q10.

The survival of a business enterprise is critically related to social responsibility

Q11.

Business has to have a social responsibility beyond making profit

Fig. 2 shows the responses of items $7-11$ of the questionnaire. Responses to Q7, Q8, Q9, and Q11 indicate that the employees $(58 \%)$ seem to have a consensus on the point that business has a social responsibility beyond making profit. Majority of the respondents (50\%) also believe that being socially responsible is most important and that it is $(48 \%)$ essential for the long-term profitability of the firm.

\section{B. Social responsibility and Sustainability}

Corporates today have accepted their responsibility to do no harm to the environment. Self-regulation and voluntary activities have now become a norm. The environmental aspect of CSR accompanies sustainability of the firm.

There is a conscious effort by firms to minimize practices that might adversely affect the enjoyment of the country's resources by future generations. Hence the formulated hypothesis was:

H2:

there is a linear relationship between importance of CSR and sustainability

\begin{tabular}{|l|l|l|l|l|}
\hline \multicolumn{2}{|l|}{ Table V: Statistics } \\
\hline & $\begin{array}{l}\text { Mea } \\
n\end{array}$ & $N$ & $\begin{array}{l}\text { Std. } \\
\text { Deviation }\end{array}$ & $\begin{array}{l}\text { Std. Error } \\
\text { Mean }\end{array}$ \\
\hline $\begin{array}{l}\text { Importance of } \\
\text { CSR }\end{array}$ & 4.12 & $\begin{array}{l}33 \\
6\end{array}$ & .908 & .050 \\
\hline $\begin{array}{l}\text { CSR \& } \\
\text { Sustainability }\end{array}$ & 4.31 & $\begin{array}{l}33 \\
6\end{array}$ & .917 & .050 \\
\hline
\end{tabular}

\begin{tabular}{|c|c|c|c|}
\hline \multicolumn{4}{|c|}{ Table VI. Correlation between variables } \\
\hline Importance of CSR & $N$ & Correlation & Sig. \\
\hline $\begin{array}{l}\text { and CSR } \\
\text { Sustainability }\end{array}$ & 336 & .672 & .000 \\
\hline
\end{tabular}

Using 0.05 level of significance, $\mathrm{t}_{\text {STAT }}$ is 4.648 with 335 degrees of freedom. Also, the $\mathrm{p}$ - value is zero (which is less than 0.05). Table $\mathrm{V}$ hereby indicates that there is a linear relationship between 'Importance of CSR' and 'Employee directed CSR'. Table VI depicts the strength of the relationship as a positive 0.7 .

Inference:

There is strong linear relationship between Importance of CSR and it is directly interrelated with sustainability of the organization.

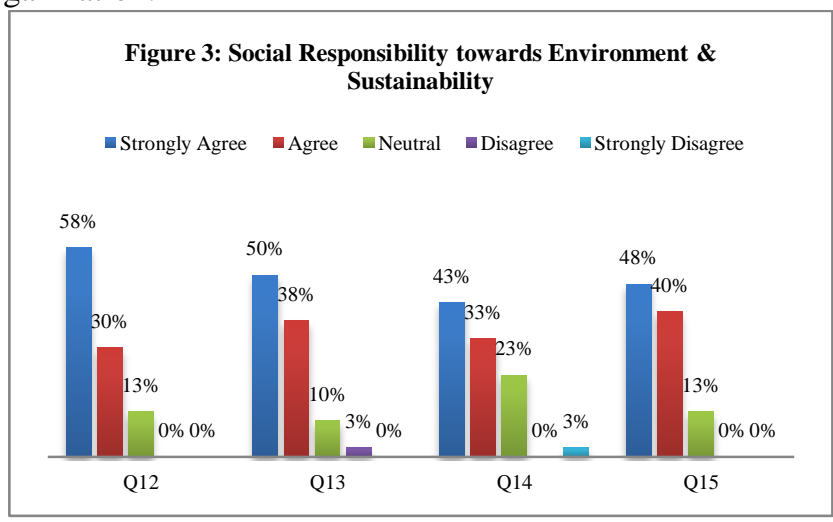

Q12.

The company participates in activities that aim to protect and improve the quality of the environment 
Q13.

The company makes investment to create a better life for the future generations

Q14.

The company implements special programs to minimize its negative impact on the natural environment

Q15.

The company targets a sustainable growth that takes into consideration the future generations

Fig. 3 shows the responses of items $12-15 \mathrm{ba}$ of the questionnaire. Responses to Q12 - Q15 illustrate that even though organization's are not directly allied with environmental concerns. Employees are conscious towards the natural environment and sustainable growth which considers CSR an investment to create better life for future generations.

\section{DISCUSSION}

This study was aimed at examining the existence of a linear relationship between the importance of CSR and its influence on other factors viz. employee directed CSR, sustainability etc. Based on the analyzed data, it can be concluded that there is a linear relationship between the importance of CSR by an employee and various other factors of CSR.

With the in Companies Act, 2013 it is obligatory for companies to spend at least $2 \%$ of its profits on CSR. Indian firms would be one of the major contributors to this CSR corpus. They are now at the focal point of successful implementation of CSR initiatives. Indian firms need to demonstrate how CSR can contribute directly to sustainability of the enterprise. This can be achieved only if the employees learn to appreciate the importance of CSR and its role in the core business. Sensitization of the employees towards significance of CSR is indispensable at this juncture.

The findings indicate a need to strengthen the roles and responsibilities of the employees who will drive the CSR Programmes. Employees must recognize and accept their role in community development. Its time organizations became more efficient and effective as organizations where CSR is nurtured. It is vital that all employees (Top level to bottom level) demonstrate a strong pledge towards CSR undertakings and weave it into the cultural fabric of their firm.

CSR can act as a tool for firms and social enterprises in enabling changes in their business model. Firms can make attempts to generate societal value by addressing critical social and environmental needs that are within its business reach. These attempts may not return immediate business profits, but would foster in making the business model sustainable.

\section{LIMITATIONS}

Since the scope of the paper is limited to firms based in the city of Pune only. Hence, broad conclusions cannot be derived from the current study. The findings cannot be generalized to the entire Indian industry and the corporate world. Future studies may overcome this limitation by

increasing the scope and sample size, thereby ensuring better representation of Corporate India.

\section{REFERENCES}

1. Fiona Mcdonald et al, "The perceptions of employees in a private Higher education institution towards corporate social responsibility" SA Journal of Human Resource Management, 2006, pg. 27-35

2. Asghar Babania et al, "An examination to effects of Gender Differences on CSR", 2nd World Conference on Business, Economics and Management-WCBEM2013, 2014, pg. $664-668$

3. Carroll, A. 1979. A three-dimensional model of corporate performance. Academy of Management Review, 4: 497 505.

4. Robins, Fred. (2005). The Future of Corporate Social Responsibility. Asian Business \& Management, Vol. 4, pp. 95-115.

5. Peterson DK (2004). The relationship between perceptions of corporate citizenship and organizational commitment. Bus. Soc., 43:296-319

6. Ashforth, B. E. and F. Mael: 1989, 'Social Identity Theory and the Organization', the Academy of Management Review 14(1), 20-39. Doi: $10.2307 / 258189$.

7. Elkington, J. (1997), Cannibals with forks - Triple bottom line of 21 st century business, Stoney Creek, CT: New Society Publishers.

8. Backhaus, K B, Stone, BA \&Heiner,2002,'Exploring the relationship between corporate social performance and employer attractiveness', Business and Society, vol.41,no.3,pp.292-318

9. Daily, C.M., Dalton, D.R. and Cannella, A.A. (2003), "Corporate governance: decades of dialogue and data", Academy of Management Review, Vol. 28 No. 3, pp. 371-82.

10. Turker, D. (2009). How corporate social responsibility influences organizational commitment. Journal of Business Ethics, 89(2), 189-204. doi: 10.1007/s10551008-9993-8.

11. Turker, D. (2009b). Measuring corporate social responsibility: A scale development study. Journal of business ethics, 85(4), 411-427. doi: 10.1007/s10551008-9780-6.

12. Tajfel, H. \& Turner, J.C. (1986). The social identity theory of group behavior. In: H. Tajfel (Ed.), Psychology of intergroup relations(pp.15-40). Cambridge, UK: Cambridge University Press.

\section{AUTHORS PROFILE}

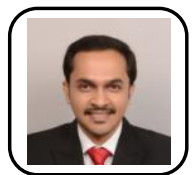

Dr. Naval Lawande is an Assistant Professor at Symbiosis Institute of Management Studies, Pune. He has considerable exposure in Strategy, Social Responsibility, and Information Systems apart from in-depth study in the field of Human Resource Management. He has interacted and collaborated extensively with managers having significant industry experience on varied projects. His research interests include corporate social responsibility, human resources, emotional 
intelligence, strategic management and organizational behavior. He has a Doctorate degree from Savitribai Phule Pune University in Organization Management. Dr. Naval has a teaching, research and consulting experience of over a decade in the above-mentioned areas. He is Member of many Professional associations and International organizations. 